\title{
Prevalence and Risk Factors of Asymptomatic Gallstone Disease in North-East Part of Bangladesh
}

\author{
${ }^{1}$ Madhusudan Saha, ${ }^{2}$ Kamrun Nahar, ${ }^{2} \mathrm{MM}$ Arif Hosen, ${ }^{2} \mathrm{MH}$ Khan, ${ }^{3}$ Shasanka Kumar Saha \\ ${ }^{3}$ Bimal Chandra Shil, ${ }^{3}$ Md Habibur Rahman
}

\begin{abstract}
Background: The study was designed to assess the prevalence of asymptomatic gallstone disease in North-East part of Bangladesh.

Materials and methods: Randomly selected asymptomatic persons, unknown to have gallstone disease, from both rural and urban areas were enrolled. They were subjected to abdominal ultrasonography and findings were recorded in a data sheet.

Results: Total 1,019 persons (316 males and 703 females) were examined. Age of them varied from 18 to 80 years with mean age of 37.22 years. Out of them, $61(6 \%)$ persons were found to have gallstone. Among them, 14 were males and 47 were females. Both male and females of age below 40 years were more affected. Gallstone disease was found more commonly among housewives and middle class people. Among 61 patients with gallstone, seven were underweight (11.47\%), 32 $(52.45 \%)$ had normal weight and $22(36.06 \%)$ were overweight, obese or extremely obese. But, this difference was not statistically significant $(p=0.894)$.
\end{abstract}

Conclusion: Prevalence of asymptomatic gallstone disease was found in $6 \%$ apparently healthy subjects of North-East part of Bangladesh. It was more prevalent among housewives and middle class group of population. It is also common among the people of age group below 40 years.

Keywords: Asymptomatic gallstone, Prevalence of gallstone disease, North-East Bangladesh.

How to cite this article: Saha M, Nahar K, Hosen MMA, Khan MH, Saha SK, Shil BC, Rahman MH. Prevalence and Risk Factors of Asymptomatic Gallstone Disease in North-East Part of Bangladesh. Euroasian J Hepato-Gastroenterol 2015;5(1):1-3.

Source of support: Nil

Conflict of interest: None

\section{INTRODUCTION}

The prevalence of gallstone disease (GSD) shows geographical variations. It occurs commonly in western countries. ${ }^{1,2}$ Most are asymptomatic, but still, GSD contributes substantially to healthcare cost and its complications are sometimes life-threatening. ${ }^{1-3}$ Epidemiological studies show that $80 \%$ subjects with GSD are asymptomatic. ${ }^{1-4}$ The prevalence of GSD is $15 \%$ in Sweden, ${ }^{5} 14.5 \%$ in Mexico; ${ }^{6}$ while, in Italy, it is $5.9 \% .{ }^{7}$ In Asian countries, Taiwan has the highest prevalence of GSD at $20 \%{ }^{8}$ Whereas the prevalence of GSD in Japan and Thailand are 3.2 and 3.5\% respectively. ${ }^{9,10}$ In India, the prevalence rate is 0.00 to $8.1 \%$ in men and 2 to $29 \%$ in women. ${ }^{11}$ Asymptomatic GSD is being increasingly detected nowadays as result of the widespread use of ultrasonogram..$^{12}$ Real-time ultrasonogram is a simple, noninvasive and relatively less costly method for diagnosis of GSD with sensitivity up to $95.5 \%{ }^{13}$ In Southern coastal region of Bangladesh, one study was done among rural people showing overall prevalence of gallstone disease at $5.4 \%\left(7.7 \%\right.$ in women and $3.4 \%$ in men). ${ }^{14}$ This study was done to see the prevalence of asymptomatic GSD in the North-East part of Bangladesh.

\section{MATERIALS AND METHODS}

This study was done between January 2012 and December 2012 in the Centre of Nuclear Medicine and Ultrasound, Sylhet, Bangladesh. Randomly selected apparently

\footnotetext{
${ }^{1}$ Department of Gastroenterology, North East Medical College, Sylhet, Bangladesh

${ }^{2}$ Nuclear Medicine and Ultrasound Center, Sylhet, Bangladesh

${ }^{3}$ Department of Gastroenterology, Sir Salimullah Medical College, Dhaka, Bangladesh
}

Address reprint requests to: Madhusudan Saha, Associate Professor, Department of Gastroenterology, North East Medical College South Surma, Sylhet, Bangladesh, Phone: +8801711367847, e-mail: madhunibedita@gmail.com 
healthy people of age 18 years and above from Sylhet city and adjacent villages were included in this study. Any person known to have gallstone disease or previously investigated for gallstone disease was excluded. Epidemiological data and physical findings were recorded in a data sheet. Then, sonological examination was done by two senior sonologists of the center separately using Machine Sonoline G60 S (Company Siemens, Erlangen, Nuremberg, Germany). In case of doubt, the person was examined by senior most sonologist of the center. Around five persons were examined at each working day. Criteria for diagnosis of GSD were as follows:

- One or more echogenic structures in gall bladder lumen with posterior acoustic shadow.

- One or more echogenic structures without posterior acoustic shadow but changing position during changes of posture.

- A strongly echogenic structure in the region of gallbladder with distal acoustic shadow in case of limited or nonvisualization of lumen.

\section{STATISTICAL ANALYSIS}

Statistical analysis was done by using SPSS version 12 and $\chi^{2}$ test was done to see significance. $\mathrm{p}$-value $<0.05$ was taken as significant.

\section{RESULTS}

Total 1,019 persons were enrolled in this study. Among them, $316(31 \%)$ were males and $703(69 \%)$ were females. Age of them varied from 18 to 80 years (mean 37.22 years). Out of them, 402 participants ( 123 males and 279 females) were from rural areas and 617 (195 males and 424 females) were from urban area. Out of 1,019 participants, gallstone was found in $61(6 \%)$ subjects. Among them, 14 were males and 47 were females $(p=0.16)$. Within male participants, prevalence was higher below the age of 40 years. In females, prevalence of gallstone disease was found higher below the age 40 years and more marked below 30 years. Total 27 persons had single stone and rest 34 had multiple stones (Table 1).

Gallstone was found more among housewives (42; $68.85 \%$ ) followed by service holders $(9 ; 14.75 \%)$. In this study, middle class socioeconomic group was found to be more affected (30; 49.1\%) followed by poorer people (26; $42 \%)(p=0.3886)$. Among the persons having gallstone disease, only three $(4.9 \%)$ were smokers and $13(21.31 \%)$ used to take betel nut and tobacco leaves.

Among all 61 persons having GSD, seven were underweight, 32 were normal weight, 17 were overweight and five were obese and extremely obese $(p=0.894)$. The prevalence of GSD in relation to age group and body mass index (BMI) has been shown in Tables 2 and 3 respectively.

\section{DISCUSSION}

Prevalence of asymptomatic GSD in North-East part of Bangladesh in this study was found to be $6 \%$ among adults. It is similar to another report from southern coastal region of this country which was $5.4 \%{ }^{14}$ It is higher than the prevalence in Japan ${ }^{9}$ and Thailand, ${ }^{10}$ but similar to that of Italy ${ }^{7}$ and Germany. ${ }^{15}$ But, this is lower than that of Taiwan, ${ }^{8}$ Sweden $^{5}$ and Mexico. ${ }^{6}$

Table 1: Relation of gallstone disease with demographic variables

\begin{tabular}{|c|c|c|c|}
\hline & Total & GB stone & Percentage \\
\hline Male & 316 & 14 & 4.43 \\
\hline \multirow[t]{2}{*}{ Female } & 703 & 47 & 6.68 \\
\hline & 1019 & 61 & 5.98 \\
\hline \multicolumn{4}{|l|}{ Education } \\
\hline Primary and below & 528 & 35 & 6.62 \\
\hline Up to HSC & 374 & 20 & 5.34 \\
\hline Above & 117 & 6 & 5.12 \\
\hline \multicolumn{4}{|l|}{ Occupation } \\
\hline Housewife & 602 & 62 & 10.29 \\
\hline Student & 37 & 3 & 8.108 \\
\hline Service & 216 & 9 & 4.166 \\
\hline Business and farming & 79 & 3 & 3.797 \\
\hline Day labor and others & 60 & 4 & 6.66 \\
\hline \multicolumn{4}{|l|}{ Glucose tolerance } \\
\hline Diabetic & 63 & 3 & 4.76 \\
\hline Nondiabetic & 956 & 58 & 6.066 \\
\hline \multicolumn{4}{|l|}{ Economic class } \\
\hline Poor & 505 & 26 & 5.148 \\
\hline Middle class & 435 & 30 & 6.896 \\
\hline Rich & 79 & 5 & 6.32 \\
\hline \multicolumn{4}{|l|}{ Personal habit } \\
\hline Smoker & 103 & 3 & 2.91 \\
\hline Nonsmoker & 916 & 58 & 6.33 \\
\hline Betel nut chewer & 166 & 13 & 7.83 \\
\hline Nonbetel nut chewer & 853 & 48 & 5.627 \\
\hline
\end{tabular}

Table 2: Prevalence of gallstone disease in different age groups

\begin{tabular}{lllll}
\hline Age groups & Population & GB stone & Male & Female \\
\hline$\leq 30$ years & 392 & 23 & 4 & 19 \\
$31-40$ years & 313 & 17 & 4 & 13 \\
41-50 years & 188 & 10 & 1 & 9 \\
$>50$ years & 126 & 11 & 5 & 6 \\
\hline
\end{tabular}

Table 3: Relation of gallstone disease with BMI

\begin{tabular}{llll}
\hline BMI & $\begin{array}{l}\text { Total } \\
\text { population }\end{array}$ & Gallstone & Percentage \\
\hline Underweight & 93 & 7 & 7.52 \\
Normal weight & 585 & 32 & 5.47 \\
Overweight & 278 & 17 & 6.11 \\
Obese & 61 & 5 & 8.19 \\
Extreme obese & 1 & 0 & 0 \\
\hline
\end{tabular}


These differences maybe due to differences in ethnicity, geographical environment and food habit and lifestyle. Prevalence of gallstone disease is found higher among women than men in this study. It is consistent with other reports. $1,5-7,16,17$

In this study, prevalence was higher among the people of below 40 years which is not consistent with other reports ${ }^{11,18,19}$ where increasing age was found one of the common risk factor for GSD. The number of participants of higher age group was less in the present communication. Obesity has not been found to be a significant risk factor which is also inconsistent with other reports from our country ${ }^{14}$ and Europe. ${ }^{11,19}$ However, subjects the number of overweight and obese participants were also small. But, other non-European reports ${ }^{9,11,19}$ did not support the association of obesity in the formation of gallstone. This may be due to nature of stone, lifestyle of population and environmental factors. Black stones are related with hemolytic diseases and brown stones are related with stasis and infection in biliary system. Obesity plays role at least in part in formation of cholesterol stones which is infrequent in Asians and common in Europeans. ${ }^{15}$

This study revealed that middle class and poorer people are more affected by gallstones which are consistent with reports from Britain. ${ }^{20}$ But, this differs from the other study in Bangladesh. ${ }^{14}$ It maybe explained as the number of participants of higher socioeconomic group was small in this study.

Prevalence of GSD is found to be significantly higher among housewives, which is consistent with reports from southern part of our country, ${ }^{14}$ and Italy. ${ }^{20}$ But, Swedish reports do not support it. ${ }^{21}$ Smoking habit, habit of betel nut and tobacco leaves chewing, diabetes mellitus and hypertension showed no significant influence on the prevalence of gallstone disease in this study.

\section{REFERENCES}

1. Attili AF, Carulli N, Roda E, Barbara B, et al. Epidemiology of gallstone disease in Italy: prevalence data of the multicentre Italian study on cholelithiasis. Am J Epidemiol 1995;141(2): 158-165.

2. Barbara L, Sama C, Morselli Labate AM, et al. A population study on the prevalence of gallstone disease: the Sirmione Study. Hepatology 1987;7(5):913-917.

3. Janzon L, Aspelin P, Eriksion S, Hildell J, Trell E, Ostberg H. Ultrasonographic screening for gallstone disease in middleaged women: detection rate, symptoms and biochemical features. Scand J Gastroenterol 1985 Aug;20(6):706-710.

4. Berger MY, VanderVelden JJ, Lizmer JG, Decart H, Prius A, Pohnen AM. Abdominal symptoms: do they predict gallstones? A systematic review. Scand J Gastroenterol 2000 Jan;35(1):70-76.

5. Muhrbeck O, Ahlberg J. Prevalence of gallstone disease in a Swedish population. Scand J Gastroenterol 1995 Nov;30(11): 1125-1128.

6. Mendez-Sanchez N, Jessuran J, Ponciano G, Atonso-de-Ruiz P, Uribe M, Hernandez-Avila M. Prevalence of gallstone disease in Mexico: a necropsy study. Dig Dis Sci 1993;38(4):680-683.

7. Loria P, Dilengite MA, Bozoli M, et al. Prevalence rates of gallstone disease in Italy: the chinciano population study. Eur J Epidemiol 1994;10(2):143-150.

8. Su Ch, Lui WY, Peng FK. Relative prevalence of gallstone diseases in Taiwan: a nationwide cooperative study. Dig Dis Sci 1992;37(5):764-768.

9. Nomura H, Kashiwagi S, Hayashi J, et al. Prevalence of gallstone disease in general population of Okinawa, Japan. Am J Epidemiol 1988;128(3):598-605.

10. Prathnadi P, Miki M, Suprasert S. Incidence of cholelithiasis in the northern part of Thailand. J Med Assoc Thai 1992;75(8): 462-470.

11. Khuroo MS, Mahajan R, Zargar SA, Javed G. Prevalence of biliary tract disease in India: a sonographic study in adult population in Kashmir. Gut 1989;30(2):201-205.

12. Glambec I, Amesjo B, Soreide O. Correlation between gallstones and abdominal symptoms in a random population: results from a screening study. Scand J Gastroenterol 1989; 24(3):277-281.

13. Portincasa P, Moschetta A, Petruzzeli M, Palasciano G, Di Ciaula A, Pezzolla A. Gall stone disease: symptoms and diagnosis of gallstone. Best Pract Res Clin Gastroenterol 2006;20(6):1017-1029.

14. Dhar SC, Ansari SM, Saha M, Ahmad MM, Rahman MT, Hasan M, Khan AKA. Gallstone disease in a rural Bangladeshi community. Indian J Gastroenterol 2001 Nov-Dec;20(6): 223-226.

15. Kratzer W, Mason RA, Hill V, Hay B, Hang C, Adler G, et al. Gallstone prevalence in Germany: the Ulm gallbladder stone study. Dig Dis Sci 1998 Jun;43(6):1285-1291.

16. Jorgensen T. Gallstones in Danish population: fertility period, pregnancies and exogenous female hormone. Gut 1900 Apr; 29(4):433-439.

17. Novacek G. Gender and gallstone disease. Wien Med Wochenschr 2006 Oct;156(19-20):527-533.

18. Glambek L, Kvalee G, Arneso B, Soreide O. Prevalence of gallstone in Norwegian population. Scan J Gastroenterol 1987;22(9):1089-1094.

19. Sampliner RE, Bennett PH, Comess LJ, Rose FA, Burch TA. Gall bladder disease in pima Indians: demonstration of high prevalence and early onset by cholecystography. N Engl J Med 1970 Dec 17;283(25):1358-1364.

20. Murry FE, Logan RFA, Hannaford PC, Kay CR. Cigarette smoking and parity as risk factors for the development of symptomatic gallbladder disease in women: result of the Royal College of Practitioners' oral contraceptive study. Gut 1994;35(1):107-111.

21. Borch K, Jonsson KA, Zdolsek JM, Kullman E. Prevalence of gallstone disease in a Swedish population sample: relation to occupation, childbirth, health status, lifestyles, medications and blood lipid. Scand J Gastroenterol 1998;33(11):1219-1925. 